\title{
ON RHAGOVELIA OBESA, UHLER.
}

BY J. R. DE LA TORRE BUENO, NEW YORK.

Rhagovelia, Mayr,* is well characterized by the long spindle-shaped deeply-cleft intermediate tarsi, a peculiarity noted by most of the authors who have referred to the genus. This genus is found in Asia, Africa and the three Americas, but the larger part of the known species is native to the Western Hemisphere, no less than fifteen (including undescribed forms in my collection) being Central American. All the species are fluviatile, save two, which are marine. The marine forms are found in estuaries or along the coasts, and by some authors are held to form a different genus, known as Trochopus.

The one species to be found commonly in the Eastern United States is Ubler's Rhagovelia obesa, $\dagger$ which can be found in almost any swift streamlet in little congregations, weaving zigzags where the current is most rapid, swimming against it, or else sheltered in the eddy behind some projecting rock, where, in the latitude of New York, the rare winged form is most likely to be found. My collection contains specimens from the following regions: New York, New Jersey, Washington, D. C., and North Carolina. The various local lists we have mention it as occurring in Tennessee, North and South Carolina, Maryland, Virginia, Pennsylvania, Massachusetts, Ohio, New Jersey, and Ontario, Canada. Prof. Uhler states that it is found in the Atlantic States.

In their generic characterization, Mayr, Stal (under the generic name Baecula) and Uhler note the deeply-cleft intermediate tarsi, but it fell to Champion to refer to the tuft of hairs in the cleft in the following terms (which Distant quotes in "Fauna of British India, Rhynchota, Vol. II., p. $\mathrm{i} 7 \mathrm{I}^{\text {") }}$ : "Rhagovelia is well characterized by the 3 -jointed tarsi, and the long, deeply-fissured terminal joint of the intermediate tarsi. In this fissure there is a series of long ciliated hairs arising from a common stem, which are probably extended fan-like when the insect moves about on the surface of the water; these hairs are sometimes partly extended in dried specimens, but they are usually hidden within the fissure."

Champion's remarks on the hairs are substantially correct, as can be

*Verh. Zool., bot. Ges. Wien., XV., 445, 1865. Reise der Novara, Hem., i8 8 .

+187 . Proc. Bost. Soc. N. H., XIV., 107.

$¥ 865$. Hemiptera Africana, Vol. III., p. I67.

\$19or: Biologia Centrali Americana, Heteroptera, Vol. II., p. I3 .; , ;

February, 1907. 
seen from the accompanying figures $(3,4$ and 5$)$, but his surmise as to the manner of their employment is ambiguous in form, because under it

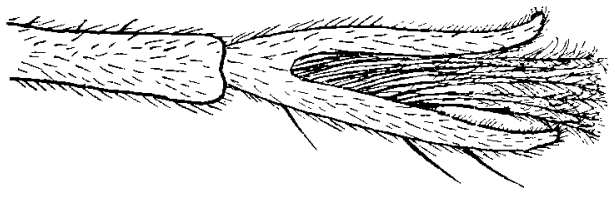

Fis, 3.--Rhagovelia obesa, Uhler. Third joint of intermediate larsus, showing cleft and swimming hairs, $x$ to. (Original.)

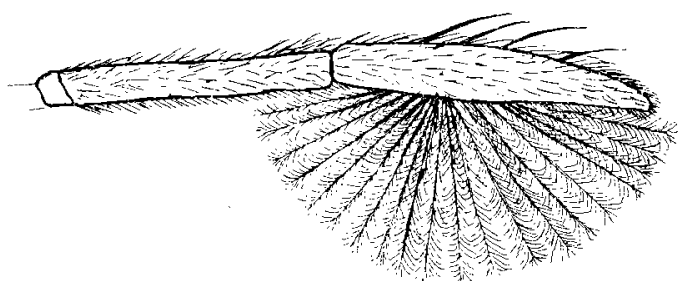

FII. 4,-Rhagovelia obesa, Uhler. Tarsus of intermediate, showing ciliated swimming hairs spread. Side view. $x$ ro. (Original.)

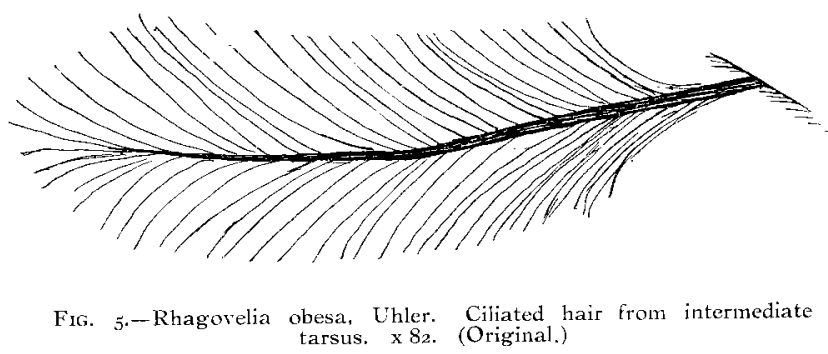

one may conclude that they are spread out upon the surface to support the bug, or else that they are employed in propeling the insect when moving about on the surface. At any rate, he merely states an hypothesis in vague terms, based on the appearance of the structures and in the absence of direct observations. The abundance of Rhagovelia obesa about New York has made it possible to study the living Hemipteron on a number of individuals I secured for that purpose. I had over twenty living specimens in an aquarium this past summer (1906), under close observation, and the following notes are taken from my field-book, $i_{n}$ which I noted the behaviour of the living bugs as I watched them. 
The manner of using the tarsal hair tuft, it should be noticed, is very difficult to observe satisfactorily, as the active bug moves its legs very swiftly when swimming. At times, however, either through exhaustion from long-continued rowing, or through weakness in partly drowned individuals, they move the legs more slowly, so it is possible to see the use of the hairs plainly, of which, when swimming fast, it is possible to get only the merest glimpse. The ciliated hairs (figs. 3, 4 and 5), are extended fan-wise (fig. 4), as may sometimes be seen in dried specimens.

The tarsus is in contact with the water along its entire length, with the slit vertical to the surface. When in this position the spread tuft of hairs projects beneath into the water, and is a powerful auxiliary in swimming. When swimming under water the hair tuft is also expanded, and is of great assistance. The necessity for an aid in swimming at the surface is explained by the fact that Rhagovelia is to be found in the swiftest part of streams, where it may be seen zigzagging against the current in little schools, which in June and July are made up principally of the sexes in copulo. The very young nymphs betake themselves to sheltered and still nooks along the banks.

In cop. the $f$ is above, as is usual with insects. When the of first seizes the $q$ she endeavours to throw him off, and flings herself on her back with the of under her. After a moment's struggle they right themselves. During this the $f$ sets the hind femora at right angles to his body, bending the tibiæ under, and, by means of them, holding the $q$ 's second and third pair of legs straight and close to her body. Once he is firmly on her, he releases this hold, but maintains his position by the anterior legs, which clasp the $q$ over the prothorax. He is not connected with the $q$ continuously while on her back. To complete the act, he seizes her as at first, by means of the hind legs. At other times he merely lies on her back quiescent, with his second and third pairs of legs extended, but not touching the surface. As long as the $\delta$ is on her the $q$ does all the swimming.

It is known that Rhagovelia swims freely under water, and to my disgust the individuals $I$ had persisted in diving. They were taken in the afternoon, and being put in an aquarium, when night came, they took to diving. By I r p.m. they were all actively swimming under water. To penetrate the surface film they put the head down at the surface, and, by means of a few vigorous swimming-strokes with the intermediates, they force themselves under. When under water they swim about freely and rapidly by means of the intermediates, the tarsal swimming-tuft being fully 
expanded. In order to come out they swim strongly upwards, and the head breaking through the surface film, the body is forced out by vigorous strokes. When the entire body has emerged it is still held by the surface film, but the dorsum is dry, the velvety pile which clothes the insect shedding the water. Now, by main strength, the legs are lifted free from the prisoning film, and, when this is accomplished, a few strong heaves and jerks liberate the body, and the bug once more glides over the water. Under water Rhagovelia appears to be made of silver, owing to the large quantity of air carried down by it enmeshed in its pile.

Rhagovelia is predaceous in common with all the Gerrids, and feeds on such insects as fali into the water, or on its own kind when there is no other food. The winged form is very rare in this latitude, although it is quite common in species from the tropics. The majority of the species of this genus have incrassate hind tarsi in the male, in some cases out of all proportion to the size of the bug.

\section{NEW SPECIES OF NORTH AMERICAN LEPIDOPTERA. BY WM. BARNES, S. B., N. D., DECATUR, ILLINOIS.}

(Continued from page 1.5.)

Tricholita artega, n. sp.--Expanse, $40 \mathrm{~mm}$.

Fore wing reddish-brown, slightly hoary from a thin admixture of whitish scales. Markings distinct though not contrasting, except white scales on outer side of reniform and the pale orbicular. Basal half line present, dentate, double, pale filled. T. a. almost transverse, scalloped, double, pale filled. Median shade present though not prominent, rather darker brownish-red than rest of wing, as are the other lines. T. p. evenly excerted beyond cell, thence in rather a straight line to inner margin, scalloped between veins, the outer accompanying line barely indicated. The pale filling between the lines is specially indicated on costa and inner margin. Two or three pale points on costa beyond t. p. line. S. t. pale, irregular, rather diffuse, preceded by a slightly darker shading. Veins, especially through terminal and subterminal space, slightly darker: Fringe yellowish-white at base, darkened outwardly. The wing is somewhat lighter along costa and inferior portion of median space, from the increase in number of white cells in these portions. Orbicular a somewhat round yellowish spot, pale contrasting with ground colour. Reniform long, slender, upright, with faint black ring, especially marked on outer side, filled through outer half and lower end with white scales, the remaining portion being of the ordinary ground colour.

February, т $9 \%_{7}$ 